\title{
Shared commitments towards social resilience in populations vulnerable to extreme weather conditions
}

\author{
Ana Lucía Maldonado-González, Gloria Elena Cruz-Sánchez, Laura Odila Bello-Benavides \\ and Edgar Javier González-Gaudiano, Universidad Verarcruzana, Mexico
}

\begin{abstract}
The processes involved in moving from vulnerability to resilience imply shared commitments between community and social actors. This paper documents such a shared experience among groups of high school learners from three cities in Veracruz state, Mexico, which have been periodically affected by extreme weather conditions. Earlier research carried out with high school learners and teachers analysed the resilience that the community demonstrated while coping with, and recovering from, an environmental contingency. In this initial research stage, we obtained information from official sources, and from questionnaires and interviews on the physical and social elements that impact the learners' vulnerability. In addition, we identified the participants' interest in being involved in processes to build resilient communities. With all this information, it was then possible to make progress in the development of strategies towards building the relevant capacities in those high school learners interested in becoming change agents in their own communities. The research also contributed to the creation of intra-community contingency support networks in the three municipalities participating in the study. In addition, high school learners and teachers became interested in initiating environmental protection activities and in taking on the commitment to communicate their concerns to decision-makers in their own communities to try and influence public policy. Accordingly, these actions and shared commitments can be seen to foster community and social resilience.
\end{abstract}

Key words: environmental education, climate change, vulnerability, social resilience.

\section{Resumen}

Los procesos para transitar de la vulnerabilidad a la resiliencia implican compromisos compartidos entre comunidad y actores sociales. Este artículo muestra la experiencia participativa con población joven, alumnos de bachillerato, de tres municipios del estado de Veracruz, México, periódicamente afectados por fenómenos hidrometeorológicos extremos. Se realizó con anterioridad una investigación con alumnos y docentes de bachillerato, relacionada con la resiliencia comunitaria que ellos gestionan para sobrellevar y recuperarse de una contingencia ambiental. En estas etapas iniciales de la investigación, se obtuvo información de fuentes oficiales, cuestionarios y entrevistas, sobre elementos fisicos $y$ sociales que propician su vulnerabilidad. Además identificamos el interés de los participantes por involucrarse en procesos para crear comunidades resilientes. Con esta información, fue entonces posible avanzar en el desarrollo de estrategias orientadas a la formación de capacidades en los alumnos de estos bachilleratos interesados en convertirse en agentes de cambio de sus propias comunidades. También se favoreció la creación de redes intracomunitarias de apoyo ante contingencias para los tres municipios participantes en el estudio. Asimismo, emergió el interés en los 
alumnos $y$ docentes por detonar acciones de protección y defensa ambiental, asumir el compromiso para transmitir estas preocupaciones a tomadores de decisiones en sus propias comunidades y buscar así incidir en la política pública. Se trata entonces de acciones y compromisos compartidos que pueden ser detonantes de resiliencia comunitaria y social.

Palabras clave: educación ambiental, cambio climático, vulnerabilidad, resiliencia social.

\section{Introduction}

Coastal populations are periodically affected by extreme weather conditions, which have gained in frequency and intensity in recent years. Geographical location is by itself a risk factor. These coastline zones are areas where climate change manifests more intensely. The coastline of the state of Veracruz, situated in the Gulf of Mexico, is 720 kilometres long. Many of the more than 7 million inhabitants live in the low areas of river basins adjacent to rapid response rivers. Besides this, urban growth has taken place in high-risk areas, where living conditions are precarious and there is little or no public service delivery or infrastructure. All this contributes to physical and social vulnerability and aggravates the population's conditions when facing a climate contingency. This has been the case in the study localities, which belong to the municipalities of La Antigua, Tlacotalpan and Cotaxtla, in the state of Veracruz.

This introduction is concerned with the conceptualisations of vulnerability and resilience that support the research. We will then go on to focus with more emphasis on everything related to the processes that can contribute to social and community resilience, since this resilience is embedded in the current stage of the research being conducted in these localities.

Vulnerability is associated with ecosystemic depletion, as well as with the loss or weakening of social well-being caused by environmental and social threats. Vulnerability can be studied as a pre-existing condition in a person or in a community. It can also be studied as a social product and process mediated by governmental economic and social decisions (Adger, 2000; Aguirre, 2004). Specifically, social vulnerability is defined as a community's exposure to stress following a disturbing event which has altered their means and conditions of life (Adger, 1999).

In our research, we adhere to Anderson and Woodrow's (1989) typology of vulnerability: 1) physical vulnerability (climate, location, ground, housing, public health service and education infrastructures, and productive activities of a locality); 2) social vulnerability (institutions, political system, demographics, decision-making processes and socioeconomic activities); and 3) motivational-attitudinal vulnerability (a community's self-image in terms of the skills and knowledge available to deal with a given risk and its actual occurrence).

Within this context, the approaches towards studying a community's vulnerability to a threat, and the threat's potential impact, tend to focus on: 1) vulnerability as a state of the community, where the focus is on inquiring about the economic, social, cultural and political situations which make it vulnerable (social and motivational-attitudinal vulnerability elements); 2) vulnerability as a component of the community, where the geophysical and climate conditions which make the community vulnerable are considered (i.e. the proximity to rapid response water bodies), as well as the cultural, social or economic resources the 
community are able to mobilise in order to face and overcome such vulnerability. Hence, vulnerability is not seen as an immutable state but one that can be transformed (Anderson \& Woodrow, 1989).

In epistemic congruence with this perspective on vulnerability, the risks are a stress factor for a broad sector, or all, of the community. This stress factor is the by-product of a potential threat, which could be economic, political, social or environmental (Barber, 2013). Risk is quantified using indicators, or scales, that determine the risk's probable impact in terms of the physical damage resulting from the magnitude of the threat and the degree to which the community is exposed to it (González Gaudiano \& Maldonado González, 2017).

Specifically, the risks associated with climate events are valued as one more fact of community life, mediated by political, social, economic, cultural, geographic and physical realities. It is important to understand the processes through which communities use all kinds of resources, and through which they adapt and transform their environment, as they face those climate change-related phenomena affecting their vulnerability (Adger, 1999).

Community and social resilience have been defined in several ways. Community resilience is viewed as the capacity for recovery and growth (Agani, Agani \& Landau, 2010) which allows the community to adapt to new conditions (Cheshire, Esparcia \& Shucksmith, 2015). From a different view point, social resilience is understood as the capacity for dealing with disruption (Adger, 2000), as well as the capacity for energising advantageous relationships during the recovery from the stress of a given risk (Cacciopo, Reis \& Zautra, 2011).

These conceptualisations originate from various approaches, depending on the particular response to the risk in question: 1) resist or compensate - the most basic form of response; 2) protect and recover - where the presence of risk is recognised; and 3) transform - the deepest and most complex form of resilience in response to multiple causes of risk (Adger, 1999, 2000; Kais \& Islam, 2016). Social resilience favours and energises, among its main components, the relationships of power and politics among the various social actors involved in the community managing the risks and vulnerability, such as government agents and economic, academic and social entities (Keck \& Sakdapolrak, 2013).

Other approaches consider resilience as: 1) an aspect of individual subjects or communities, or 2) as a process in which protective and risk factors interact (Ahren, 2006). The first approach here has been subject to multiple criticisms related to its conceptualisation of resilience as an aspect or characteristic of people or communities, as an attribute that is possessed or not, instead of as a dynamic process developed throughout life where the aforementioned factors interact, and which are possible to manage. Hence the importance of clarifying this condition (Earvolino-Ramírez, 2007). Another criticism of the first approach is related to its specific and temporary dimension, pointing to the need to delimit the set of protection factors that are energised when a community is faced with specific risk factors, within a given time period, and when mediated by social and contextual conditions (Fergus \& Zimmerman, 2005). In this regard, critics point out the importance of defining the protection and risk factors which unfold under the specific and dynamic character of resilience being researched, with the objective of avoiding generalisations and ambiguities regarding the phenomenon (Kais \& Islam, 2016). 
From this perspective of vulnerability and resilience, a community is characterised by its complexity, dynamism and network of relations among those who are part of it (Cheshire et al., 2015; IFRC, 2014). Its members, besides sharing exposure to the same threats and risks because of their own vulnerability, share elements that give them membership and identity. These elements, according to Kais and Islam (2016) can be of three types: 1) compositional, meaning the set of physical, social, economic and cultural characteristics and resources of a community; 2) contextual, including the geographic and climatic conditions of the environment; and 3) functional, considering the mechanisms a community manages in order to coexist, such as the actions and processes deployed to respond to risks, for example the floods these populations face every hurricane season.

Conceptualisations which consider this view of community and risks derived from climate change come from the approach to resilience as a dynamic long-term process of interaction between risk and protection factors against a hydrometeorological phenomenon. They define community resilience as the capacity acquired and fostered from community processes to face these phenomena, recover and reduce their impact, and to adapt and establish, through self-organisation, new community conditions which reduce the social vulnerability derived from such phenomena (Cheshire et al., 2015; Kais \& Islam, 2016; Landau, 2010). This capacity depends, as pointed out by Landau (2010), on the resources the community possesses, its degree of social vulnerability and the level of networking among its members in terms of trust and reciprocity, as well as on recognising the uncertainty which characterises these phenomena and influences the community's social vulnerability and its level of self-organisation (IFRC, 2014).

In the first stage of this research, the aim was to identify community resilience. In the second stage, detailed in this article, the objective was to progress towards social resilience in a collaborative manner, that is, is to tackle social vulnerability against extreme weather conditions, which is intrinsically dynamic due to the uncertainty of the phenomena and the conditions of a community (Keck \& Sakdapolrak, 2013). Social resilience takes cognisance of power and political roles, members' participation levels in the transformation, social relationships and the network structure within the uncertainty. Thus, social resilience is understood as the capacity of a community's members and social actors (government, institutions, etc.) to manage economic, material, social and cultural capitals that allow them not only to face and adapt to adverse situations but also to generate favourable environments that reduce a community's social vulnerability within its participation networks and its power and political roles (Kais \& Islam, 2016; Keck \& Sakdapolrak, 2013).

In studies on community and social resilience to extreme weather conditions (Cheshire et al., 2015; González Gaudiano \& Maldonado González, 2017; González Gaudiano, Maldonado González \& Sánchez Cruz, 2018; IFRC, 2014; Kais \& Islam, 2016; Maguire \& Cartwright, 2008), one of the main aspects is the recognition of the community's capacity for reacting to and facing these events collectively, both in terms of decision-making and acting from the capacities it already possesses as well as in terms of the prevailing economic, social, political and institutional dimensions. 


\section{Context of the study and a brief synthesis of its initial stage}

The municipalities of La Antigua,Tlacotalpan and Cotaxtla are located in the centre of Veracruz state, Mexico, in the river beds of the La Antigua, Papaloapan and Jamapa rivers, respectively. These are areas of warm sub-humid weather with summer rains, and which are constantly affected by extreme weather conditions (cyclones and tropical storms). These phenomena have led to floods in the places studied. Table 1 presents their most relevant geographic and demographic characteristics.

Table 1. Geographic and demographic characteristics of the study communities

\begin{tabular}{|l|l|l|l|}
\hline $\begin{array}{l}\text { Municipality } \\
\text { data }\end{array}$ & La Antigua & Tlacotalpan & Cotaxtla \\
\hline Locality & José Cardel & Tlacotalpan & Cotaxtla \\
\hline Population & $\begin{array}{l}19902 \text { inhabitants } \\
\text { (urban) }\end{array}$ & $\begin{array}{l}7600 \text { inhabitants } \\
\text { (semi-urban) }\end{array}$ & 1167 inhabitants (rural) \\
\hline $\begin{array}{l}\text { Temperature } \\
\text { range }\end{array}$ & $24-26^{\circ} \mathrm{C}$ & $24-28^{\circ} \mathrm{C}$ & $24-26^{\circ} \mathrm{C}$ \\
\hline Rainfall range & $1100-1300 \mathrm{~mm}$ & $1400-2100 \mathrm{~mm}$ & $1100-1300 \mathrm{~mm}$ \\
\hline $\begin{array}{l}\text { Altitude above } \\
\text { sea level }\end{array}$ & $10-100 \mathrm{~m}$ & $5-10 \mathrm{~m}$ & $10-200 \mathrm{~m}$ \\
\hline Land use & $\begin{array}{l}\text { Agriculture (34\%) } \\
\text { Urban area (3\%) }\end{array}$ & $\begin{array}{l}\text { Agriculture (21\%) } \\
\text { Urban area (1\%) }\end{array}$ & Agriculture (38\%) \\
\hline Vegetation & $\begin{array}{l}\text { Pastureland (34\%), jungle } \\
(15 \%), \text { other (11\%) }\end{array}$ & $\begin{array}{l}\text { Pastureland (66\%), } \\
\text { reed bed (7\%) }\end{array}$ & $\begin{array}{l}\text { Pastureland (55\%), } \\
\text { jungle (7\%) }\end{array}$ \\
\hline
\end{tabular}

Source: Gobierno del Estado de Veracruz (2015a, 2015b, 2015c)

In its initial stage, this study's purpose was to get to know the vulnerability and possible community resilience, identified by high school learners, to extreme weather conditions; and from this, to generate strategies which could contribute to strengthening the capacity for increasing community and social resilience.

High school learners aged between 15 and 18 participated in the study. This is a population sector distinguished by a willingness to participate in this kind of activity and to give information, both for the questionnaire applied in the first stage of the research and during the workshops of the second stage. Moreover, this group shows enthusiasm for getting involved in rescue work when confronted with extreme weather conditions. For this reason, young people are potential agents of change, as demonstrated in the first opportunity presented by an earthquake. ${ }^{1}$ 
This initial stage of the research consisted in administering a questionnaire for the purpose of gathering information on the community's vulnerability and resilience. A research survey on the physical risks these communities face when coping with floods was also carried out. In addition, semi-structured interviews with key local actors (high school principals, mayors, and civil protection and health services personnel) were conducted with the objective of triangulating the information obtained from the learners and adding depth to the data related to vulnerability and resilience. The main results of this stage have already been published. Therefore, due to limited space, we will not deal with them in any detail here (González Gaudiano \& Maldonado González, 2017; González Gaudiano et al., 2018).

\section{Development of a collaborative research project: Towards social resilience}

The second stage of the research, which will be discussed in detail here, consisted of a series of sensitisation and training activities in each locality, as well as additional activities conducted at the Universidad Veracruzana, Xalapa Campus. For this stage, high school principals in the study area were contacted in order to jointly coordinate a series of workshops aimed firstly at high school learners and later at teachers. The goal of these workshops was to introduce certain environmental topics into high schools which contributed to the collaborative acknowledgement of local problems and their possible solutions, whereby the learners worked in teams and presented their contributions. It is worth mentioning that the discussion topics were derived from the diagnoses made in the first stage of the research. Climate change was selected as the main topic because of its impact on these localities as a consequence of their geographical location. The people in these communities acknowledge the reality of climate change in the increasingly intense storms and flooding in Tlacotalpan (90\%), Cardel (61\%) and Cotaxtla (51\%), but also in the droughts, especially in Cotaxtla (81\%), and in the extreme heat waves $(60 \%$ average), which have aggravated virus-borne diseases such as zika, chikungunya and dengue, according to key informants. In all these instances, high school learners recognise problems arising for their health and for local ecosystems and, from here, their vulnerability and the consequent possibilities for social and community resilience. Social acknowledgment of a problem is the first step to collective action against it, and this understanding was identified in the first two stages of the workshops, with the participation of high school learners and teachers from these localities.

The workshops were facilitated by university professors, expert researchers in climate change, health and the environment as well as by representatives of several government agencies in the fields of environment, civil protection and health. The researchers conducting this study were also involved throughout the whole process. The workshop topics and their purposes are detailed in Table 2 and 3.

During these first two participatory workshops, carried out in-situ, the youngsters reflected on climate change, its causes, consequences and possible adaptative behaviours and disasterrelief actions. Risks, vulnerability and community resilience were also discussed. In their interventions, it is possible to detect prior learning, from their school education as well as from their own experience of Hurricane Karl and of other topics dealt with during the workshops. 
Table 2. First round of workshops (February to May 2016): Introduction to the topics

\begin{tabular}{|l|l|}
\hline Topic & Purpose \\
\hline Psychological impact of floods & $\begin{array}{l}\text { Know and understand the implications in psychological terms } \\
\text { of those who were affected by floods, as well as their individual } \\
\text { and collective management. }\end{array}$ \\
\hline Response to climatic contingencies & Understand how humans react and face risk-filled situations. \\
\hline Climate change & $\begin{array}{l}\text { Identify the causes and consequences of climate change locally } \\
\text { and globally. }\end{array}$ \\
\hline Climate change and health & $\begin{array}{l}\text { Know the health implications of climate change and how to } \\
\text { act on them. }\end{array}$ \\
\hline $\begin{array}{l}\text { Perception and prevention of the } \\
\text { risks in populations vulnerable to } \\
\text { climate change }\end{array}$ & $\begin{array}{l}\text { Know and discuss perceptions of the risks and individual and } \\
\text { collective preventive actions. }\end{array}$ \\
\hline $\begin{array}{l}\text { School projects related to the } \\
\text { environment and sustainability }\end{array}$ & $\begin{array}{l}\text { Offer ideas regarding projects about the environment and } \\
\text { sustainability that could be developed in their school and } \\
\text { locality. Based on the Green Kit Manual of BID. }\end{array}$ \\
\hline
\end{tabular}

Note: A total of approximately 250 high school learners, divided into seven groups, participated in the workshops.

Table 3. Second round of workshops (February to April 2017): Afterthoughts

\begin{tabular}{|l|l|}
\hline Topic & Purpose \\
\hline Flood-risk prevention programmes & $\begin{array}{l}\text { Present and discuss the relevance and importance of flood-risk } \\
\text { prevention programmes and their influence on high school } \\
\text { learners in these localities. }\end{array}$ \\
\hline $\begin{array}{l}\text { Consumption and ecological } \\
\text { footprint; my lifestyle's impact on } \\
\text { the planet }\end{array}$ & $\begin{array}{l}\text { Sensitise and consider consumption and ecological footprint, } \\
\text { as well as the impact of people's lifestyles on the planet. }\end{array}$ \\
\hline $\begin{array}{l}\text { Environmental conservancy and } \\
\text { quality of life }\end{array}$ & $\begin{array}{l}\text { Think about and generate action proposals for environmental } \\
\text { conservation and how it relates to the quality of human life. }\end{array}$ \\
\hline Audio-visual memory & $\begin{array}{l}\text { Presentation on audio-visual memory, its importance in the } \\
\text { study localities and how it relates to high school learners. }\end{array}$ \\
\hline Climate change & $\begin{array}{l}\text { Through a game-like experience, understand the local } \\
\text { consequences of climate change and how to generate } \\
\text { responsive actions, both individual and collective. }\end{array}$ \\
\hline $\begin{array}{l}\text { The high school teacher as a } \\
\text { promoter of social resilience }\end{array}$ & $\begin{array}{l}\text { Think about teachers' work related to promoting and managing } \\
\text { social resilience. In addition, discuss some lines of action. }\end{array}$ \\
\hline $\begin{array}{l}\text { Climate change in high school } \\
\text { subjects }\end{array}$ & $\begin{array}{l}\text { Know the syllabus areas where climate change is included and } \\
\text { how they can be used. }\end{array}$ \\
\hline
\end{tabular}

Note: A total of approximately 150 high school learners, divided into seven groups, participated in the workshops. 
Some of the learners' comments are provided below. ${ }^{3}$

[Climate change] is something that happens because of pollution, and the effects society is provoking, it is the accumulation of harmful effects for the earth, and they manifest through disasters, rains, aggressive changes, that affects us and affects the earth.

Unbearable heat, the rivers are drying, trees are disappearing, heat is getting stronger, more intense.

We also have the different diseases that happen because of these climate changes, such as breathing diseases, where there is the cold, allergies, coughing, among others. Also, the year it happened, if you realise, was the year that 'canicula' [mid-summer] lasted the longest and, there were new diseases like zika and chikungunya, also where there are too many storms, where there is intense heat.

Normally, in this city of Cardel, you never heard of storms, hurricanes or even extreme heat waves, but what is happening now is something new, because this was not an area where hurricanes or things like that entered, and, since a short time ago all these phenomenons are happening and climate change gets worse every day.

All the effects [of climate change] are linked; for example, the economic affects the social, because, for the same thing, some people lose their jobs, and, without jobs there is no sustainability in the family, which causes extreme poverty.

Figure 1. Participation of high school learners in workshops
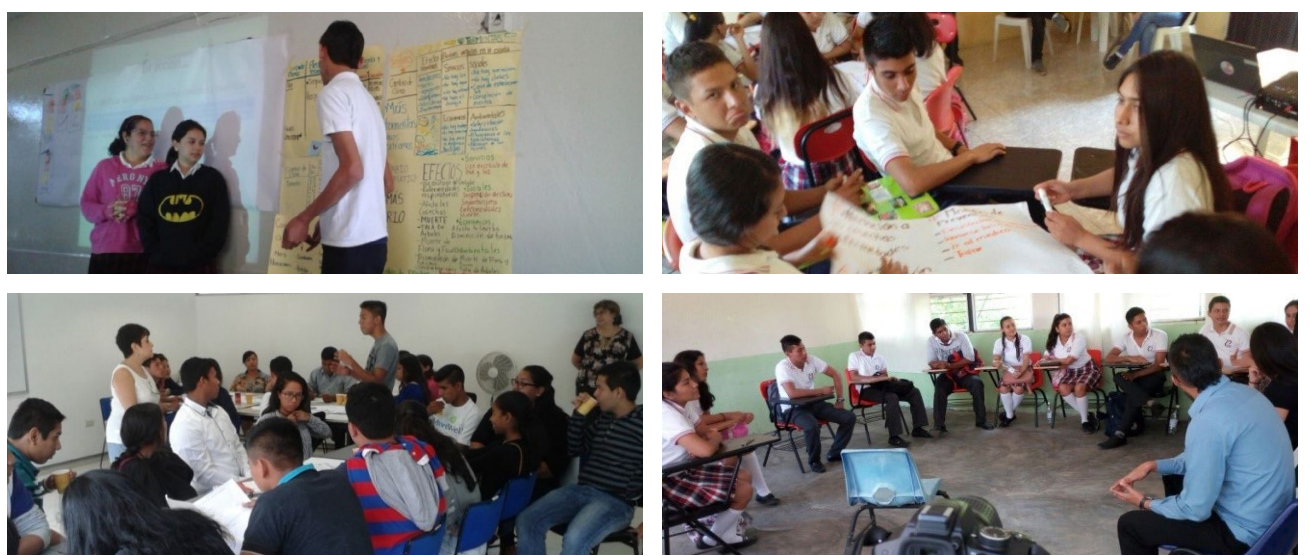
After conducting these workshops with school groups in each locality, smaller groups from each (34 pupils in total), accompanied by teachers (five in total), were invited to participate in further workshops over three days on the Xalapa Campus, Universidad Veracruzana. Many of the high school learners who attended had never been outside their localities. For this reason, the experience helped increase their motivation to pursue their studies, since there are either no higher education institutions in their localities or the higher education programmes that are available are limited. This comprised the third round of the workshops. Table 4 details the activities that were carried out.

Table 4. Third round of workshops (June 2017): Collaborative commitment among high school learners, teachers and social actors

\begin{tabular}{|l|l|}
\hline Topic & Purpose \\
\hline Risk communication & $\begin{array}{l}\text { Approaches for communicating effectively in situations } \\
\text { of high stress or community risk. }\end{array}$ \\
\hline What is climate change? & $\begin{array}{l}\text { Understand the phenomenon, its causes and } \\
\text { consequences. } \\
\text { Reflect on the implications of climate change in my } \\
\text { community. }\end{array}$ \\
\hline Disasters: debate & $\begin{array}{l}\text { Analyse, through examples presented in video clips and } \\
\text { their own testimony, how disasters are generated, their } \\
\text { anthropogenic impact, characteristics and consequences. }\end{array}$ \\
\hline Food and agriculture around the world & $\begin{array}{l}\text { Reflect on eating and food consumption styles and their } \\
\text { relationship to climate change. }\end{array}$ \\
\hline Community & $\begin{array}{l}\text { Analyse the importance of bonds within a community } \\
\text { for facing vulnerability and acting together against floods. }\end{array}$ \\
\hline Disaster prevention family plan & $\begin{array}{l}\text { In teams, develop a disaster prevention plan and discuss it } \\
\text { with the group. }\end{array}$ \\
\hline Management of social resilience & $\begin{array}{l}\text { Reflect on how social resilience can be fostered during } \\
\text { climate-change events. }\end{array}$ \\
\hline Develicipating government actors in workshops \\
\hline Community
\end{tabular}

Note:Thirty-four high school learners and five teachers participated in the workshops. 
This third round of workshops permitted a longer training programme for smaller groups of learners from each community, with the objective of increasing their participation in community brigades when next faced with a serious contingency. The rainy season of September 2017 once more caused significant damage in these places. For this reason, we visited them to find out how the learners had behaved during the emergency. There is not enough space here to narrate their complete experiences, which will be detailed in another paper. At this stage, we share the comments of some of the high school learners who participated actively in the preventive brigades in their communities:

What we did, at the end of the workshop was to continue all of us and we created a group called JOVECO, which means 'young ecologists' [Jóvenes Ecologistas in Spanish]. Then the group gathered on different occasions to visit different communities that were the most affected, to help ... (High school learners in Tlacotalpan)

We had to deal with resilience and adaptation, and we talked to other people in the community about the precautions for floods and earthquakes. We cannot prevent them, but we can talk about prevention and we talked to them, taught them, tried to make them understand. (High school learners in Cardel)

When we returned, we started with talks for our classmates who had finished the sixth semester. It was only them at the beginning. After, we organised ourselves, some others had holidays and so. And then, we returned and everyone in the school knew we had been. We talked about the workshop, how they treated us and all that... and later there was the workshop for all the school. We gave them the talk and asked them to do activities... We talked to them about how climate change affected the actions we can do to reduce pollution, how we can act in the face of a flood ... Besides, we placed signs in that building about the measures of earthquakes or floods ... We also explained the importance of the risk map, the evacuation routes, how far the river goes, in case it overflows and, well, they participated ... we divided them into teams and each team made their risk map. (High school learners from Cotaxtla)

Figure 2. Preventive signs and risk maps made by the youngsters at the workshops
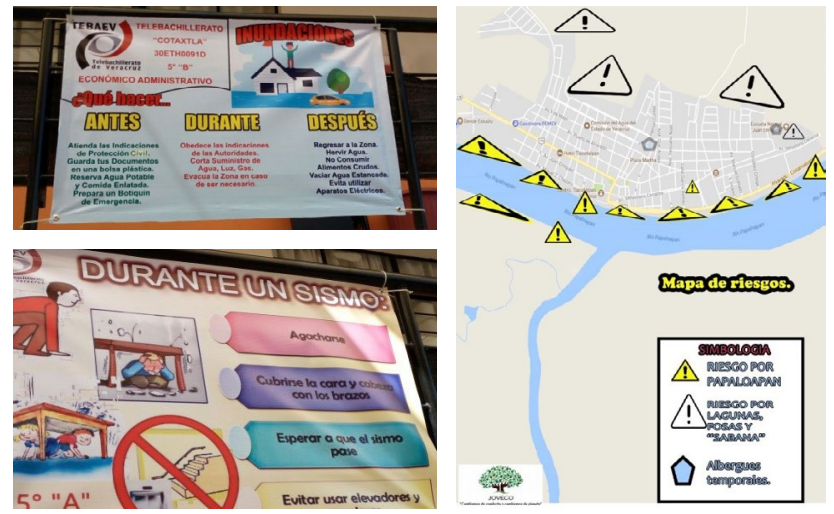
The workshops did not aim to provide solutions for the communities; their purpose was to provide information; allow collaborative reflection on their local problems and possible ways to respond to them; and to energise actions oriented towards encouraging youth and other actors' to participate in strengthening social resilience. In particular, the third round of workshops, because they were more intensive and directed, left the youngsters with an interest in setting up intra- and inter-community networks of support against climate contingencies. For this, they had to muster support from various government offices and follow up on measures that could reduce vulnerability and increase social resilience. This collaborative research aimed to promote in high school learners the capacity for organising and managing alternative ways of reducing vulnerability.

\section{Final thoughts}

The research preceding the workshops, carried out with high school learners and different social actors, enabled the researchers to understand and analyse information related to the vulnerability and resilience they identify in their own localities as well as their potential interest in getting involved by organising brigades to face any future contingencies caused by floods and thereby becoming change agents (González Gaudiano \& Maldonado González, 2017; González Gaudiano et al., 2018).

The localities in the study were severely damaged by a flood in 2010 caused by Hurricane Karl. The high school learners who participated in this study are currently between the ages of 15 and 18, which means they were children at the time of the floods. However, what happened is still present in their minds, as was noticed during the first exchanges with them when it was possible to hear emotional, shaky voices and witness tears as they remembered the devastating event. In this first stage of the research, the identification of the high school learners' vulnerability and resilience was one of the targets and, from there, set the course for the final stages of the study. It was discovered that, in all three localities, the community managed to overcome the disaster and move forward despite their physical and social conditions of vulnerability.

The motivational-attitudinal vulnerability related to the community's pre-existing or potential self-image, abilities and knowledge when facing a risk was not identified among the high school learners during the first stage of the research. Despite recognising the absence of opportunities for getting involved as change agents and the majority's stating that they interact little or never with different social actors (municipal authorities, civil society organisations, neighbouring communities, health services and civil protection units), most of the high school learners were motivated to participate in various preventive activities that could help reduce the community's exposure to disaster. Some of these activities involve 1) organising and participating in brigades to train the community in preventive measures; 2) making diagnoses and developing action plans in cases of emergency; 3) participating in informative and preventive community assemblies; and 4) joining reconstruction processes should a disaster happen.

These findings led to the next collaborative stage of the research, namely the sensitisation and training activities presented above. 
During this stage, the interest was in advancing the collaborative process and looking for social resilience, giving privilege to power relationships within the community itself and allowing them to move towards actually managing the risk rather than simply managing the disaster. Risk management implies involving all social actors in modifying together the conditions that contribute to the physical and social vulnerability of the community. Involving high school learners in the management of risk, as change agents, can lead to collaborative processes between actors from different sectors.

The sensitisation and training activities in each locality fostered the youngsters' interest in getting involved in the different activities that had been presented by the participating government actors. These activities were mainly oriented towards protective measures concerning human health and the environment. Additionally, they included civil protection activities via preparatory training so that youngsters could then be counted on should a contingency happen. A pact was made between the high school learners and the other participating actors - and it will be important to follow up on this. As a result, there was an improvement in the management and strengthening of communication networks - one of the key elements of social resilience.

Channels of communication have now been opened between the research team and the high school teachers and learners of these localities. Before the rainy season of 2017, the high school learners visited junior schools to teach them how to deal with climate-change risks. They talked to the local authorities about prevention and, during the flood season, provided direct help to the population.

Social resilience prioritises the political dimension of a community in terms of being oriented towards the engaged action of community members and towards the actions of other stakeholders whose roles cover the management of social vulnerability and the risk caused by the event in question (in this case, extreme weather conditions). Moving from community resilience to social resilience against extreme weather conditions implies setting up processes where such a dimension is energised among the members of the community and other social actors involved in official decision-making and in the gathering of knowledge related to this risk, thus boosting collaborative action networks. This process is ongoing.

\section{Endnotes}

1. On 19 September 2017, an earthquake severely affected several states in Mexico. In Mexico City, young people participated actively in the immediate activities of removing debris and mobilising help via social networks.

2. http://www.iadb.org/temas/educacion/cambio-climatico/kit-verde-escolar.18688.html

3. The comments were made in Spanish and have been closely translated by the authors. This includes the learners' comments on page 10 .

4. Secretariat of the Environment, Veracruz.

5. Secretariat of Health, Veracruz. 


\section{About the contributors and their contributions}

\section{Lead author}

Maldonado-González, Ana Lucía |

Instituto de Investigaciones en Educación, Universidad Veracruzana, Mexico |

ORCID 0000-0002-7780-8206 | anmaldonado@uv.mx

Ana Lucía Maldonado González is Professor-Researcher at the Institute of Educational Research, at the Universidad Veracruzana, Mexico. Her research topics include environmental education, climate change, vulnerability and social resilience, environmental communication and social representations.

\section{Co-author}

Cruz-Sánchez, Gloria Elena |

Instituto de Investigaciones en Educación, Universidad Veracruzana, Mexico |

ORCID 0000-0002-9394-9447 | gcruz@uv.mx

Gloria Elena Cruz-Sánchez has a $\mathrm{PhD}$ in Education. She is currently director of the Institute of Educational Research of the Universidad Veracruzana, Mexico, and a member of the National System of Researchers (SNI). Her line of research falls within the field of environmental education. She is a lecturer of the Master's and Doctorate programmes in Educational Research of the same university.

\section{Co-author}

Bello-Benavides, Laura Odila |

Instituto de Investigaciones en Educación, Universidad Veracruzana, Mexico |

ORCID 0000-0002-8261-588X | labello@uv.mx

Laura Odila Bello-Benavides has a $\mathrm{PhD}$ in Educational Research, and is an academic at the Institute of Educational Research, Universidad Veracruzana, Mexico, and a member of the National System of Researchers (SNI). Her line of research falls within the field of Environmental Education. She has authored and co-authored a number of publications related to environmental education.

\section{Co-author}

González-Gaudiano, Edgar Javier |

Instituto de Investigaciones en Educación, Universidad Veracruzana, Mexico |

ORCID0000-0002-2161-2917 | edgagonzalez@uv.mx

Edgar J. González Gaudiano is a Senior Research Fellow at the Institute of Educational Research at the UniversidadVeracruzana, Mexico, where he leads the research in environmental education for sustainability. His current research focus is on social representations of climate change, vulnerability, risk and social resilience. 


\section{Percentage contributions}

During the different stages of researching and writing this paper, the authors collaborated equally on its: 1) conception and design, theory and key argument; 2) data collection; 3) analysis and interpretation; 4) drafting; and 5) critical review.

\section{References}

Adger, W.N. (1999). Social vulnerability to climate change and extremes in coastal Vietnam. World Development, 27(2), 249-269.

Adger, W.N. (2000). Social and ecological resilience: Are they related? Progress in Human Geography, 24(3), 347-364.

Agani, F., Agani, N. \& Landau, J. (2010). Community-building before, during, and after times of trauma:The application of the LINC Model of Community Resilience in Kosovo. American Journal of Orthopsychiatry, 80(1), 138-144.

Aguirre, B. (2004). Los desastres en Latinoamérica:Vulnerabilidad y resistencia. Revista Mexicana de Sociología, 66(3), 485-510.

Ahern, N. (2006). Adolescent resilience: An evolutionary concept analysis. Journal of Pediatric Nursing, 21(1), 175-185.

Anderson, M.B. \& Woodrow, P.J. (1989). Rising from the ashes. Development strategies in times of disaster. Boulder, CO and Paris, France:Westview Press and UNESCO. Re-edited in 1998 for Intermediate Technology Publications, London.

Barber, B. (2013). Annual Research Review: The experience of youth with political conflict - challenging notions of resilience and encouraging research refinement. Journal of Child Psychology and Psychiatry, 54(4), 461-473.

Cacioppo, J., Reis, H. \& Zautra, A. (2011). Social resilience: The value of social fitness with an application to the military. American Psychologist, 66(1), 43-51.

Cheshire, L., Esparcia, J. \& Shucksmith, M. (2015). Community resilience, social capital and territorial governance. Revista de Estudios sobre Población y Desarrollo Rural, 18(enero-julio), 7-38.

Earvolino-Ramírez, M. (2007). Resilience: A concept analysis. Nursing Forum, 42(2), 73-82. DOI 10.1111/j.1744-6198.2007.00070

Fergus, S. \& Zimmerman, M. (2005). Adolescent resilience: A framework for understanding healthy development in the face of risk. Annual Review of Public Health, 26, 399-419. DOI 10.1146/annurev.publhealth.26.021304.144357

Gobierno del Estado de Veracruz (2015a). Cuadernillos municipales, Tlacotalpan. Secretaría de Finanzas y Planeación del Estado de Veracruz.

Gobierno del Estado de Veracruz (2015b). Cuadernillos municipales, La Antigua. Secretaría de Finanzas y Planeación del Estado de Veracruz.

Gobierno del Estado de Veracruz (2015c). Cuadernillos municipales, Cotaxtla. Secretaría de Finanzas y Planeación del Estado de Veracruz. 
González Gaudiano, E. y Maldonado González, A.L. (2017). Amenazas y riesgos climáticos en poblaciones vulnerables. El papel de la educación en la resiliencia comunitaria. Teoría Educativa, 29(1), 273-294.

González Gaudiano, E., Maldonado González, A.L. \& Sánchez Cruz, G.E. (2018).The vision of high school students regarding their vulnerability and social resilience to the major adverse effects of climate change in municipalities with a high risk of flooding. Psyecology: Revista Bilingüe de Psicología Ambiental, 1-12. DOI 10.1080/21711976.2018.1483568

IFRC (International Federation of Red Crescent Societies). (2014). Framework for community resilience. Geneva: IFRC.

Kais, S. \& Islam, M. (2016). Community capitals as community resilience to climate change: Conceptual connections. International Journal of Environmental Research and Public Health, 13(12), 1211. MDPI AG. DOI 10.3390/ijerph13121211

Keck, M. \& Sakdapolrak, P. (2013). What is social resilience? Lessons learned and ways. Erdkunde, 67(1), 5-19.

Landau, J. (2010). Communities that care for families: The LINC Model for Enhancing Individual, Family, and Community Resilience. American Journal of Orthopsychiatry, 80(4), 516-524.

Maguire, B., \& Cartwright, B. (2008). Assessing a community's capacity to manage change: A resilience approach to social assessment. Canberra, Australia: Commonwealth of Australia-Bureau of Rural Sciences. 
